number of, say, geologists interested in archæological problems will always be very small. It would help if such small groups could meet regularly to discuss problems and progress. It was suggested that museum staff, in particular, should be approached with the view of interesting them more in this type of work. In Denmark, pollen analysts, petrologists and archæologists are successfully collaborating at the National Museum, and it was felt that the volume of such work in Britain would remain small until some similar scheme were put into operation.

It was further stressed that definite instructions should be issued to prevent the destruction or loss of valuable material (particularly botanical and osteological) and records (for example, of the preservation of buildings), and that these should be centrally stored and suitably catalogued ; so that even if there should be no facilities for immediate examination, the material would be available later. Other sug. gestions included the preparation of sets of slides of petrological specimens from archæological finds, and organic-carbon assays (perhaps at university centres) to determine whether a sample is suitable for carbon-14 analysis. It is-as so very frequently in scientific work-most important to develop a battery of techniques for any one type of problem in order to obtain reliable results; thus no fewer than six methods were used in the recent investigation of the Piltdown mandible.

Secondly, it is important that archæologists should frame specific questions to accompany their material ; this would considerably ease the invest. igators' burden, and serve to prevent friction and loss of time. In certain cases (for example, bones) excessive cleaning prior to dispatch from the site is undesirable.

Thirdly, it was obvious from all that had been said that the closest co-operation between archæologists and scientists at all stages is essential, not forgetting regular contact between, for example, the petrologists themselves who are engaged on archæological work.

Finally, this aspect becomes vital when (as in most cases) the problem has to be considered statistically. The examination of human bones can take on a wider significance only when its results can be related geographically. Only the archæologist can tell, in the last instance, which copper implements form a homogeneous series suitable for metallurgical analysis in attempting to trace the ores that have provided the metal ; sometimes museum specimens of ores, selected on a different basis, may not include inferior material that might well have been used by early metal-workers.

In carbon-14 determinations, quite apart from the statistical errors due to equipment and method, structural differences between young and mature wood, and contamination both during and after burial may be expected to affect the results. A number of such 'rogues' have in fact been encountered, and single or even duplicate estimations may well be more misleading than helpful unless considered on a wider statistical basis. This calls for full and accurate publication of results, and the Council was urged to oppose firmly any unilateral 'editing' of scientific appendixes in archæological journals. It further points clearly to the need for planned research and, ultimately, for an Archæological Research Institute embracing all aspects and capable of both research and routine work. Concrete proposals for such a body, it was felt, should be worked out and submitted through the Council to the appropriate quarters as soon as possible.

In one of the concluding remarks the hope was expressed that, as a result of the conference which had thrown this aspect into relief, something might be done to make it easier for archæologists and scientists to understand one another; so that the archæologist could come to know the limitations of scientific techniques, and the scientist in his turn would be able to appreciate archæological requirements. The president, Dr. D. B. Harden, in thanking members of the conference on behalf of the Council, had no doubt that the latter would be glad to do what it could, particularly about 'vetting' material sent for expert examination, in order not to strain the limited resources available. He said that he and other archæologists present had been most encouraged by the support given to the conference; if an Archæological Research Institute still seemed a long way off, it was well worth while working towards it in the best possible way.

As reported in Nature of October 9, p. 677, a Scientific Research Committee for Archæology has now been formed by the Council. Further details may be obtained from the Assistant Secretary, Council for British Archæology, 10 Bolton Gardens, London, S.W.5.

L. BIER

\section{PHYSICS OF CLOUDS AND PRECIPITATION}

A $\mathrm{N}$ international symposium was held at the Federal Institute of Technology, Zurich, during October 4-6, under the auspices of the Swiss Federal Commission for the Study of Hail Formation and Prevention, to discuss recent developments in the physics of clouds and precipitation and in the artificial modification of clouds. After the delegates had been welcomed by Prof. R. Sänger, president of the Commission, opening addresses were given by H. Dessens (France) on some theories of cloud nucleation submitted to experimental test, and by B. J. Mason (Great Britain) on the physics of natural precipitation processes.

M. Dessens described studies at the Pûy de Dome of the freezing of water droplets and the growth of ice crystals in the laboratory. The droplets, supported on spiders' threads, were suspended in a cold chamber on the stage of a microscope. Although large drops generally froze at higher temperatures than small ones, he obtained no elear-cut relation between drop size and freezing temperature because the freezing mechanism appeared to be propagated along the thread. However, large drops could be maintained at temperatures above $-12^{\circ} \mathrm{C}$. for many minutes without freezing.

The seeding of natural supercooled stratus clouds with silver iodide produced ice crystals if the temperature was below $-4^{\circ} \mathrm{C}$. and was often followed by precipitation and partial dissipation of the cloud. The seeding of similar clouds with 'dry ice' generally resulted in overseeding in the neighbourhood of the source, but precipitation and dissipation of the cloud did not follow. Large-scale seeding with silver iodide was carried out in the Pyrenees during 1951-53, but the effect on the rainfall was inconclusive. Clouds in this region tended to glaciate naturally if their summits were colder than $-15^{\circ} \mathrm{C}$.

Mr. Mason reviewed the present state of knowledge concerning the physical mechanisms which are 
responsible for the release of precipitation from both shower- and layer-type clouds. Having traced recent theoretical developments, he analysed the information which has resulted from the exploration of clouds by aircraft and radar to illustrate the conditions under which rain might be produced either by the growth of ice crystals or by the coalescence of water droplets, and to point out how the cloud behaviour might be influenced by geographical and climatic conditions. The conclusion was that in middle latitudes the majority of rain from stratiform clouds is produced by the ice-crystal process and that the coalescence process is normally responsible for only drizzle or light rain. The radar echo from precipitating warm frontal clouds can be satisfactorily interpreted in terms of the growth and multiplication by splintering of ice crystals, their aggregation to form snowflakes, and the aggregation during melting of the latter to form raindrops. In the case of showers, however, it is considerably more difficult to decide which of the possible mechanisms may be dominant.

Calculations on the growth of precipitation elements in model clouds indicate the conditions under which showers may be released by coalescence (initiated, for example, by large hygroscopic nuclei), by the growth of ice particles, by the shedding of water drops from wet hailstones and by a process of raindrop multiplication due to disruption of large drops (raindrop chain reaction). In middle latitudes during the summer, and particularly over the sea, the coalescence process may forestall the ice particles in releasing precipitation even though the tops of the clouds may afterwards show glaciation. This may account for the fact that hail falls from only a small fraction of these clouds. The coalescence mechanism will be even more favoured in the deep, warm clouds of tropical regions where the conditions may often be suitable for the rapid multiplication of raindrops by a chain reaction.

In a session devoted to atmospheric aerosols, E. M. Fournier d'Albe described how the concentration and size distribution of large hygroscopic nuclei were measured at five ground-level stations in Pakistan. Near the coast the concentrations of particles with mass greater than $10^{-9} \mathrm{gm}$. were of order $100 / \mathrm{m}^{3}$ but fell off rapidly inland. Although these particles were depleted during heavy rain, there was some evidence that hygroscopic nuclei were left behind when raindrops evaporated before reaching the ground. Dr. Fournier d'Albe thought that the main source of these particles was the sea and that they were responsible for releasing showers by initiating a chain reaction in the warm cumulus clouds of Pakistan.

O. Vittori (Italy) described microchemical tests for identifying microscopic and submicroscopic particles. The particles when caught on gelatine containing dissolved salts produce coloured rings of precipitate ; particles of mass down to $10^{-15} \mathrm{gm}$. may be detected. This technique has been used to identify sulphate and chloride particles in the atmosphere and also various artificial aerosols such as silver nitrate. Some preliminary experiments for the physico-chemical detection of minute silver iodide particles were also described. It is not yet possible to determine accurately the masses of the particles by these methods.

Prof. C. G. Rossby (Stockholm) showed some results which had emerged from the chemical analysis of rainwater in Sweden, in particular the geographical distribution of various elements as measured over a two-year period. The total deposits of sodium and chlorine fell off very rapidly from west to east, much more rapidly than does the rainfall. The ratio chlorine/sodium by weight in the deposit showed a definite geographical pattern with values of $1 \cdot 2$ near the coast falling off to $0 \cdot 6$ well inland; these values have to be compared with a ratio of 1.8 for sea water. The distribution of calcium was fairly uniform over the country, but the ratios of calcium/sodium and potassium/sodium were generally much higher than those found in sea water.

In studying the supercooling of water drops supported on a metal plate, W. Rau (Germany) has found some evidence for the spectrum of freezing nuclei having maxima at $-4^{\circ} \mathrm{C},{ }^{\circ}-11^{\circ} \mathrm{C}$. and $-19^{\circ} \mathrm{C}$. Aqueous solutions show the same general spectrum of freezing nuclei but displaced to lower temperatures. Dr. Rau believes that precipitation from natural clouds tends to occur at rather welldefined temperatures and that this can be explained in terms of his spectra of freezing nuclei. He has measured the ice nucleus contents of air samples of different origin and has found polar air masses to contain many very efficient ice nuclei which are absent from subtropical air ; he concludes that these nuclei were of maritime origin. He believes that the freezing of supercooled cloud droplets at $-40^{\circ} \mathrm{C}$. is brought about by freezing nuclei and that spontaneous nucleation occurs only at temperatures below $-70^{\circ} \mathrm{C}$. when cubic ice crystals are formed. He said that he had repeated his earlier experiments in view of criticisms that his apparatus may have been con. taminated by alcohol, and he now reported that he can confirm his earlier results.

G. Soulage (France), having grown ice crystals in the atmosphere and allowed them to evaporate, found that their residues could act as centres for the formation of ice crystals at temperatures between $-12^{\circ}$ and $-15^{\circ} \mathrm{C}$. The particles had no particular crystalline shape, were partly insoluble and partly hygroscopic and acted as ice nuclei only after liquid water had condensed on them.

In a discussion on eloud physies, H. Byers (Chicago) described recent studies of cumulus clouds in Puerto Rico and in the middle of the United States with radar-equipped aircraft. The tropical clouds forming over the sea were relatively slow-growing and gave radar echoes when little more than $6,000 \mathrm{ft}$. deep, so that they were entirely below the $0^{\circ} \mathrm{C}$. isotherm. Those forming over the island, however, showed much more rapid development, but did not precipitate until they attained considerably greater depths. The cloud droplets of tropical cumulus had a bimodal size distribution with maxima diameters of $10-15 \mu$ and $30-50 \mu$, the latter no doubt being responsible for starting the coalescence process. In order to illustrate further the geographical differences of cloud populations, Prof. Byers also reviewed radar studies made of summer cumulus in New Mexico, which often reaches great heights without precipitating, and of thunderstorms in Ohio where the initial radar echo, in the majority of cases, is entirely below the $0^{\circ} \mathrm{C}$. level, suggesting that the precipitation is initiated by coalescence.

F. H. Ludlam (London) described the observations made in central Sweden this summer as a part of a field-programme organized jointly by the Imperial College of Science and Technology, London, and the Institute of Meteorology, University of Stockholm. The behaviour of cumulus was studied with the aid of small aircraft, double theodolites, time-lapse 
photography and radar. Particular attention was paid to the growth-rates of the clouds, their development during the day and the onset of precipitation. Careful studies of the glaciation of cloud summits indicated that this sometimes occurred at temperatures as high as $-4^{\circ} \mathrm{C}$. Showers sometimes fell from clouds little more than $1 \mathrm{~km}$. deep.

The instrumentation of the aircraft of the British Meteorological Research Flight was described by R. J. Murgatroyd. A very rapid hot-wire thermometer was used to determine the thermal structure of the air below the bases of cumulus, while the airflow around the sides of the cloud was studied by following the relative motions of packets of 'window' with radar. Vertical currents inside clouds were measured with an integrating accelerometer and the liquid-water content with both a hot-wire instrument and a refrigerated icing disk. With the latter instrument, full adiabatic values of the water content were found in cold clouds. Measurements of the drop-size distribution in clouds by means of slides coated with either magnesium oxide or oil showed drops of radius 20-25 $\mu$ near the bases of stratocumulus clouds which were occasionally observed to produce rain if more than 4,000 ft. thick. Mr. Murgatroyd has evidence that in southern England summer showers are often released by coalescence and that even small cumulus often contains many drops of diameter $50 \mu$. Ice crystals appeared in detectable numbers only at temperatures below $-12^{\circ} \mathrm{C}$.

V. J. Schaefer (United States) outlined the cloud physics programme of the Munitalp Foundation, in particular the attempts to make a survey of cloud development at various sites in the United States with the help of voluntary observers using ciné cameras. He showed a number of colour films of clouds taken by members of the United States Forestry Service and of eloud systems which were associated with jet streams. M. Bossolasco (Milan) described some observations of precipitating clouds made at a mountain observatory and attempted to correlate the onset of precipitation with the temperature at screen level. G. Fea (Rome) reported on methods which were used to measure liquid-water content of clouds on Monte Cimone. G. Yamamoto (Japan), in his studies of the initial growth stage of ice crystal on nuclei of silver chloride and silver nitrate, has found crystals which are square rather than hexagonal prisms.

The main contribution on cloud seeding came from E. Bollay, who has conducted large-scale commercial trials in the United States, mainly with the object of increasing the snowpack in the lee of the Sierras. Silver iodide smoke was released on all occasions when clouds in the target area surpassed the $-5^{\circ} \mathrm{C}$. evel. The results were evaluated using a regression method in which past rainfall data were used to obtain a regression curve between the rainfall of the target and a control area, this being used to predict the rainfall to be expected naturally in the target area during the seeding period. Mr. Bollay estimates that in four successive years of operations in the Central Sierras they increased the snowpack by $27,21,7$ and 22 per cent respectively. An independent assessment of three other operations by the Statistical Laboratory of the University of California suggests that in one case the rainfall showed a decrease, in another there was a considerable increase, the third being inconclusive.

In recognizing that there are certain factors which militate against commercial undertakings being able to carry out seeding experiments in the most scientifically acceptable form, Mr. Mason said that it is important for those interested in the purely scientific aspects of the problem to give considerable thought to the design and execution of a large-scale experiment. The results can be evaluated only on a statistical basis, and he indicated how an experiment might be designed using control and target areas, the decision to seed being made on the basis of a random choice. Such an experiment would probably take at least five years if rainfall increases of order 15 per cent were to be detected with reasonable confidence. Dr. Fournier d'Albe showed a film to illustrate how warm cumulus clouds were inoculated with salt particles dispersed from the ground in two areas in Pakistan. Particles of mass greater than $10^{-9} \mathrm{gm}$. were dispersed at a rate of $10 \mathrm{gm}$. $/ \mathrm{sec}$., about half being carried aloft by the air. Although there was some preliminary indication that the rainfall was higher in the target regions than outside, a complete analysis of the results has not yet been made.

After three days of lectures and discussions, visits were arranged to the Institute for Snow and Avalanche Research on the Weissfluhjoch, Davos, and to the observatory of the Meteorologische Zentralanstalt at Locarno. These gave delegates an opportunity of seeing something of this beautiful country in which they were received with such friendliness and hospitality. B. J. Mason

\section{MARIE CURIE CELEBRATIONS IN WARSAW}

THE twentieth anniversary of the death of Marie Sklodowska-Curie was celebrated at a special session of the Polish Academy of Sciences at Warsaw during October 6-8. This session was attended by Mrs. Irene Joliot-Curie, Madame Curie's daughter, and by specialists on various aspects of radioactivity from China, Czechoslovakia, France, Great Britain, Hungary, Norway and the U.S.S.R., as well as by a large number of Polish scientists who had gathered there from all parts of the country: Madame Curie's elder sister was a guest of honour, and in spite of her great age she was present at all the numerous functions of the session.

The first two days of the session were partly devoted to official speeches and surveys of the various physical and medical applications of radioactivity. Noteworthy was the speech by Mrs. Irene Joliot-Curie, in which she analysed her mother's work in a most vivid and personal way. Moreover, the participants attended the inauguration of a museum devoted to Madame Curie and installed in the newly rebuilt house where she was born in the so-called "New City" (which is actually an eighteenth-century extension of the old Town). In this museum an extensive collection of documents and apparatus pertaining to Madame Curie is displayed in a most effective manner. The successive rooms are devoted to Madame Curie's childhood and family circle, her years of study in Paris, her great work in eollaboration with her husband, her activities in promoting the medical use of radioactivity and her leadership of the Institut du Radium at Paris. 'The last rooms evoke the development of nuclear physics, which had its origin in the discovery of radioactivity, and lead the visitor to an impressive display of photo- 